\title{
Prevalence of Intestinal Parasitosis in Chronic Diarrhea among Art Naïve HIV Infected Patients in Kano, Northern Nigeria
}

\author{
Uchechukwu Ihesiulor ${ }^{1 *}$, Abdulrasak Audu², Azeez Akande ${ }^{1}$ \\ 1*Department Of Medical Microbiology And Parasitology, Faculty Of Clinical Sciences, College Of Health Sciences, Bayero University, \\ Pmb 3011, Kano, Nigeria \\ 2department Of Medicine, Federal Medical Centre, Gusau, Nigeria
}

Corresponding Author

Uchechukwu Ihesiulor $^{* *}$

Email: gabihesiulor[at]yahoo.com

Phone: +2348034504612

\begin{abstract}
Aim: To determine the prevalence of intestinal parasitosis and spectrum of parasites in chronic diarrhea among AntiRetroviral Therapy (ART) naive, Human Immunodeficiency Virus (HIV) infected patients in Kano, northern Nigeria. Recently, coepidemic of diarrhea and HIV has been on the increase especially in the developing areas of sub-Saharan Africa resulting in significant morbidity and mortality. Materials and Methods: The prevalence of parasitosis and spectrum of associated parasites were determined in 95 ART naïve HIV infected patients with chronic diarrhea at Aminu Kano Teaching Hospital (AKTH) and Infectious Disease Hospital (IDH), in Kano, Northern Nigeria. Stool samples were analyzed microscopically using concentrated method; Kinyoun modified acid-fast stain and trichrome stain techniques for the detection of oocytes and spores of parasites respectively. The prevalence of parasitosis was evaluated in relation to demographic characteristics of the study population. Results: Analysis showed that 52 (54.7\%) ART naïve HIV infected patients had parasitosis comprising mainly Entamoeba histolytica (21, 22.1\%), Microsporidia (16, 16.8\%), Cryptosporidia $(12,12.6 \%)$, Hookworm (6,6.3\%). Multiple parasitosis were observed in 13 (13.7\%) patients. There was no significant difference (P>0.05) in age (P=0.23), gender $(P=0.06)$ and weight $(P=0.90)$ of the patients in relation to the prevalence of parasitosis. Conclusion: The high (54.7\%) prevalence of parasitosis among ART naïve HIV infected patients at AKTH and IDH calls for adoption of routine diagnosis with specific and sensitive technique for the detection of parasitosis to guide all inclusive chemotherapy for this category of patients.
\end{abstract}

Keywords: Prevalence, intestinal parasitosis, ART naïve patients, Kano, Nigeria

\section{Introduction}

Diarrhea is the most frequently reported gastrointestinal symptom in HIV infected individuals with cumulative lifetime incidence rate of $30-70 \%$ in industrialized countries, and up to $100 \%$ in the developing countries (Nigeria inclusive) ${ }^{(1-2)}$. If untreated, it may lead to severe complications and significant mortality among HIV/AIDS patients ${ }^{(3)}$

Chronic diarrhea is defined as greater than three loose or watery stools per day lasting more than four weeks at presentation, and is associated with increased morbidity and mortality in HIV infected patients ${ }^{(4)}$.

The etiology of diarrhea in HIV patients is diverse, with infective agents ranging from viruses, bacteria, fungi and parasites $(5,6)$. Also, certain drugs including (protease inhibitors and antibiotics) used for treatment of HIV/AIDS might cause diarrhea as side effects ${ }^{(7)}$. As at 2014, an estimated 36.9 million people were living with HIV globally while $69.9 \%$ (25.8 million) of the infected global adults and children are in sub-Saharan Africa ${ }^{(8)}$. In Nigeria, an estimated 3.4 million people were living with HIV by the end of 2012 and is widely recognized as the second largest country (after South Africa) in the world with people living with HIV/AIDS (PLWHA) ${ }^{(8,9)}$.
Intestinal parasites particularly helminthes are still prevalent in Nigeria. Previous studies ${ }^{(10,11)}$ showed rates of $40 \%$ in apparently healthy adults and children with commonest isolates being Ascaris lumbricoides, Trichuris trichuria and Hookworm. While some reports indicate that pathogenic Protozoa are less common in some parts of Nigeria, other studies have indicated that these organisms, particularly the coccidian parasites are common in apparently healthy individuals as well as HIV infected patients with diarrhea ${ }^{(12,13)}$. Some studies carried out in North Central Nigeria in ruminants (Cattle, sheep and goats) showed a prevalence of $13 \%$ and $17 \%$ for Cryptosporidium and Microsporidium species respectively (13)

Pastoral farming is a major occupation in northern Nigeria while in-house rearing of ruminants is common in most Nigerian homes. This practice together with lack of access to safe water, poor environmental hygiene, contamination of well water and municipal water source and close human contact with domesticated animals are widely believed to be responsible for the transmission of these organisms to human populace in the area.

Infection by the coccidian is self limiting in immunecompetent individuals but causes several protracted diarrhea in the immune-compromised ${ }^{(2,14)}$. Earlier studies carried out in Enugu (South Eastern Nigeria) ${ }^{(15)}$ and in 


\section{International Journal of Science and Research (IJSR) \\ ISSN (Online): 2319-7064}

Index Copernicus Value (2013): 6.14 | Impact Factor (2014): 5.611

Zaria, (North Western Nigeria) ${ }^{(16)}$ indicate that nonopportunistic parasites are more prevalent in HIV patients with diarrhea but with rarity of opportunistic coccidian parasites (Cryptosporidia and Microsporidia). However, studies carried out in North Central ${ }^{(17)}$ and South Western Nigeria $^{(19)}$ showed that coccidian parasites may not be as rare as previously thought.

In this study, we aimed to determine the spectrum of parasites including coccidian pathogens involved in chronic diarrhea in HIV infected ART naïve patients in this environment, and to further sensitize strategy for prevention and control of these parasites in HIV seropositive patients. We are not aware of any previous studies on this subject matter in this locality; i.e. Aminu Kano Teaching Hospital (AKTH) and Infectious Disease Hospital (IDH) where the current study was conducted.

\section{Materials and Methods}

Recruitment of participants for this study was done in two major hospitals viz, AKTH and IDH. AKTH is a tertiary hospital situated in Kano, an ancient cosmopolitan city located in the Savannah zone of northern Nigeria. The hospital has a 350 bed capacity that serves Kano State of Nigeria with a population of over 10 million, and the four neighbouring States of Kaduna, Katsina, Jigawa and Yobe. AKTH has a well established Gastroenterology Unit, and an Institute of Human Virology Centre, including HIV/AIDS project that offers comprehensive services to people living with HIV/AIDS (PLWHA). At present, over 6000 adults of PLWHA are on various antiretroviral therapy regimens offered by PEPFAR (President's Emergency Plan for AIDS Relief). IDH on the other hand, is a secondary hospital located in the same city of Kano. It is a 250 bed capacity hospital offering services to people with infectious diseases including HIV/AIDS. IDH also offers comprehensive services to PLWHA and are funded by international organizations in collaboration with the Federal Government of Nigeria. At present, more than 8000 registered PLWHA are receiving cares in these two hospitals.

This was a prospective, descriptive and cross-sectional study. It involved patients with HIV associated chronic diarrhea attending PEPFAR clinic at AKTH clinic and IDH in Kano, Nigeria. The subjects consisted of consecutive HIV seropositive ART naïve patients whose HIV status were determined by two sequential rapid HIV antibody tests (HIV $1 / 2$ STAT-PAK ASSAY, USA and Uni-Gold, Ireland). The inclusion criteria were as classified by World Health Organization (WHO) and Centre for Disease Control (CDC). These include:

1)Adult patients (18 years and above) with confirmed diagnosis of HIV infection and were not on antiretroviral therapy (i.e. antiretroviral therapy naïve).

2)Patients who satisfied the clinical diagnosis of chronic diarrhea disease, while the exclusion criteria used include: (a) failure to give consent (b) patient on antiprotozoa drugs or broad spectrum antibiotics in the 2 weeks preceding enrolment into the study and those on ART at presentation as well as (c) patients on drugs such as laxatives, antacids or bismuth salts during the preceding two weeks.

Socio-demographic information and risk factors variables associated with acquisition of parasitosis were obtained via a questionnaire.

\section{Laboratory Investigation}

Patients were instructed to defecate into a clean, dry bed pan devoid of urine, disinfectant or antiseptics. Stool specimen was taken using disposable spatula or disposable plastic spoons and then placed into two sterile plastic containers one of which contains an equal volume of $10 \%$ formaline as a preservative.

The unpreserved stool specimens were examined immediately using saline wet mount in order to identify motile trophozoites and larvae. Another wet mount tinted with Lugol's iodine was then prepared for each sample already examined with saline mount, in order to rule out the presence of ova and cysts. Examination of both samples prepared with saline and Lugol's iodine were carried out using X10 followed by X40 objectives respectively.

The preserved stool specimens were stored in the refrigerator at $-4^{0} \mathrm{C}$ for analysis. Formal ether concentration was then performed on each formalinpreserved stool specimen using bucket centrifuge at a revolution of $2000 \mathrm{rev} / \mathrm{min}$ for 10 minutes, and a drop of the processed stool specimen was then examined directly, and also by tinted Lugol's iodine.

In addition, air dried stool smears from the processed stool deposit were subjected to Kinyoun modified acid fast stain (Modified Ziehl-Neelsen) ${ }^{(19)}$ for the detection of Oocysts of Cryptosporidium, Isospora and Cyclospora. Oocysts were indentified based on their relative sizes and shapes: Spherical (Cryptosporidium parvum) (4-6 $\mu \mathrm{m})$ fig. 1, Cyclospora cayetanensis $(8-10 \mu \mathrm{m})$ fig. 2, Isospora belli which is elliptical $(25-30 \mu \mathrm{m})$ as shown in fig. 3.

Microsporidial spores were identified by commercially modified trichrome stain, Webergreen protocol (Code 1489, Diasys, Bershire, UK). The manufacturer's instructions were methodically and carefully followed. Briefly, a thin smear of the test stool was made on greasefree slide, air-dried and fixed in methanol for 5 minutes. This was rinsed with acid alcohol for 10 seconds and in 95\% alcohol for 5 seconds. Subsequently, the stained smear slide was placed in $100 \%$ alcohol for 10 minutes for dehydration and cleared with xylene for 10 minutes. A mordant (mountant) was placed on the stained slide, covered with cover-slip and examined under microscope using oil immersion(x100) objective.

Microsporidia spore appears as a bright pinkish ovoid and retractile structure measuring approximately $1-2 \mu \mathrm{m}$ with belt-like horizontal or diagonal strips (Fig. 4). Standard positive microscopic slides (positive control) were used to aid identification of the coccidian parasites. 


\section{International Journal of Science and Research (IJSR) \\ ISSN (Online): 2319-7064 \\ Index Copernicus Value (2013): 6.14 | Impact Factor (2014): 5.611}

\section{Statistical Analysis}

Data were entered and analyzed with Epi info (version 6.04, CDC, Atlanta, GA). The prevalence of parasites was expressed in simple proportions and percentages for the study group. Comparisons of the group regarding age, gender, body weight and prevalence of parasites were analyzed using Chi-square test or two tailed Fisher's exact tests for categorical variables and student's t-test for continuous variables, including Mann-Whitney test as appropriate. A P-Value $<0.05$ was considered statistically significant. The approval to carry out the study was sought and approved by Ethical Committee of the Hospital (AKTH).

\section{Results}

Three thousand, four hundred and thirty four $(3,434)$ newly diagnosed HIV-infected antiretroviral therapy naïve patients were seen in the two centres within the period of 12 months. Out of this figure, 140 (4.1\%) patients who had chronic diarrhea and satisfied the inclusion criteria were originally recruited. However, only 95 patients who gave their consent and responded with stool specimens were analyzed and constituted the study group. The general demographic characteristics of the subjects are shown in table 1 . There were 45 males and 50 females (male: female ratio $=1: 1.1$ ), with a mean age of $36.0 \pm 10.3$ years (range $18-70$ years) from urban (34.7\%), slum (33.7\%) and rural (31.6\%) settlements. They were predominately unemployed $(42.1 \%)$ or self employed (farming and trading, 28.4\%), while majority of them had Arabic or primary education (64.3\%). The patients mean weight was $48.30 \pm 10.40$ (range 28 to $80 \mathrm{~kg}$ ).

The identified potential risk factors for diarrhea included consumption of locally made salad, raw vegetables, fruits and dairy foods (92.6\%) and livestock (45.3\%). Pit latrine (84.2\%), VIP toilet (10.5\%), and public toilet (9.5\%) were the major methods of faecal disposal while $4.2 \%$ of patients utilized open field for faecal disposal. Sachet water $(70.5 \%)$, well water $(50.5 \%)$, borehole $(40 \%)$, and tap water (35.8\%) were the main sources of drinking water by the subjects.

All patients were heterosexual, and 44.25 admitted to multiple sexual partners. Other risk factors for HIV transmission included use of potentially contaminated needles $(44.1 \%)$, blood transfusion $(6.3 \%)$ and accidental injury (3.2\%).

The stool was watery, mucoid only, and contained mucus and blood in 82 (85.3\%), 31 (32.6\%) and 26 (27.4\%) patients respectively. Nineteen (20\%) patients had semiformed stool while frankly bloody stool was noted in 5 (5.3\%) patients.

Of the ninety five antiretroviral therapy naïve patients with chronic diarrhea, 52 (54.7\%) had parasitic infestation. Patients with parasitic infestation and those without are compared in tables 2 and 3. They did not differ significantly in gender (male, $51.9 \%$ versus $41.9 \%$, female $48.1 \%$ versus $58.1 \%, \mathrm{P}=0.33)$, age $(34.92 \pm 8.99$ years versus $37.81+11.52$ years, $\mathrm{P}=0.22)$, duration of diarrhea (5.0 weeks (4.84) versus 6 weeks (4.52), $\mathrm{P}=0.05$ ), stool frequency $(4.87 \pm 2.30$ versus $4.80 \pm 2.30, \mathrm{P}=0.87)$, and in their various methods of faecal disposal, sources of water supply in places of residence (Table 2). Although, majority of patients (78 out of $95,(82.1 \%)$ had a CD4 cell count of

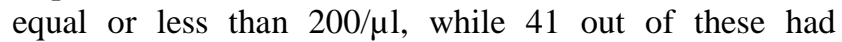
parasites isolated in their stools. Similarly, subjects with or without parasitic infestation did not differ significantly in the two CD4 cell count strata $(\leq 200$ or $>200 / \mathrm{UI}, \mathrm{P}=0.36)$, and in the presence of acquired immune deficiency syndrome as defined by 2008 CDC classification system for HIV infection in adults and adolescents; (92\%) versus 83.7\%, $\mathrm{P}=0.20$ ) (Table 3).

A total of 52 (54.7\%) ART naïve HIV infected patients had parasitosis. Ten different parasites were isolated. The common ones included Entamoeba histolytica, 21 (22.1\%) Microsporidia 16 (16.8\%), Cryptosporidia 12(12.6\%), Hookworm 6(6.3\%) and others 11(11.6\%) (Table 4). Multiple parasitic infestations were observed in 13 (13.7\%) patients while 39 (41.0\%) had single parasitic infestation (Table 5). Of the 10 different types of parasites isolated, $60 \%$ and $40 \%$ were non-opportunistic and opportunistic parasites respectively. Out of the 95 patients studied, non-opportunistic, opportunistic and mixed (i.e. a combination of non-opportunistic and opportunistic) parasitic infestation were observed in 24 (25.3\%), $20(21.0 \%)$ and $8(8.40 \%)$ patients respectively (Table 6). Patients with different patterns of parasitic infestations were compared in Table 5. They did not differ significantly in age $(\mathrm{P}=0.30)$, gender $(\mathrm{P}=0.06)$, weight $(\mathrm{P}=0.90)$ CD4 count $(\mathrm{P}=0.23)$ and $\mathrm{CDC}$ classification $(\mathrm{P}=.16)$. There were also no statistically differences in all other variables tested. Multiple parasitic infestations were also found in $13(13.7 \%)$ of the patients. Twelve (12, 12.65) of the patients had dual infection, and only one (1.1\%) had triple parasites (Cryptosporidium, Cyclospora, and Microsporidium). The age, gender, CDC and WHO staging as well as sources of water and means of faecal disposal did not differ significantly among patients with single or multiple patristic infestations (Tables 5 and 6).

\section{Discussion}

The outcome of the present study showed that there were variations in the prevalence of coccidian parasites isolated in relation to other reported various local studies, (15-18) perhaps due to differences in study methodology and level of parasite endemicity in the community. In this study, a relatively higher isolation rate of Microsporidia (16.8\%) was observed compared to that reported by Ibrahim et al. $(8.9 \%)^{(20)}$. This may be explained by the use of a relatively more sensitive and newer staining technique (modified trichrome stain) for the identification of Microsporidia in the current study, compared to studies carried out by other researchers elsewhere in Nigeria $^{(15,16,18)}$ where no stain or any specific analytical technique for the isolation of Microsporidia was utilized. The use of modified trichrome stain confers an advantage of higher isolation rate for Microsporidia, because it contains 10 times the concentration of chromophore 2R used in ordinary trichrome stain ${ }^{(19)}$. The high isolation rate 


\section{International Journal of Science and Research (IJSR) \\ ISSN (Online): 2319-7064 \\ Index Copernicus Value (2013): 6.14 | Impact Factor (2014): 5.611}

of Microsporidia in this study may also be possibly explained by possible high endemicity of this parasite in the community. Ikeh et al., in Jos (17) reported high infection rates for Microsporidia and to a lesser extent, Cryptosporidium parvum, in both apparently healthy human population and their domesticated animals in Jos and a rural village of Buruku, all located in the north central region of Nigeria. It may therefore be speculated that some of the patients in the current study might have had these infestations prior to HIV infection.

In neighbouring Cameroon ${ }^{(20)}$, a lower parasite prevalence rate (33\%) and isolation rates for individual parasites (Microsporidia 5.2\%) Entamoeba histolytica 4.5\%, Cryptosporidium parvum 3.3\%) were observed probably because the study was carried out mainly on HIV infected patients. Moreover, some of the patients in the study were already on antiretroviral therapy at the time of the study, a potentially confounding factor, as a boost in immunity from this treatment may result in lower rates of parasite detection.

Studies in Zambia ${ }^{(21)}$, Zimbabwe ${ }^{(19)}$ and Ethiopia (22) showed a parasite prevalence of between $29 \%$ to $79.4 \%$, and which was probably due to a wide geographical variation and differences also, in methodology employed in these studies. Gumbo et al., in Zimbabwe ${ }^{(19)}$ reported a comparatively higher isolation rate for Microsporidia (18\%) using modified trichrome stain and 51\% using polymerase chain reaction (PCR) followed by Crytosporidia (9\%) using light microscopy alone. In this study, polymerase chain reaction was not utilized, and this may indicate that the prevalence obtained may be an underestimation of the actual prevalence of Microsporidia in Kano.

Studies in the United States ${ }^{(23)}$ and Europe ${ }^{(24)}$ in HIV infected patients have shown that Protozoan parasites were more common than the helminthes, which is similar to that obtained in this study. The overall parasite isolation rate was lower in the study carried out in the United States compared to that obtained in this current study $(18.5 \%$ versus $54.7 \%$ ), but comparably similar higher values (57\%-70.6\%) were obtained in the French studies ${ }^{(23,24)}$. This may be explained by differences in the study methodology, and study area. However, like in this study, protozoan parasites were more common than helminthes, the commonest parasites isolated being Microsporidia, accounting for $11-29 \%$ of isolates, while Cryptosporida accounted for $7.4 \%$ to $17.4 \%{ }^{(27,28)}$

Though Entamoeba histolytica was the most prevalent parasite in this study perhaps due to its high endemicity in the environment, however, the similarities in the isolation of opportunistic parasites may be explained by the improved techniques. While the low prevalence of helminthes infestation reported in the developed countries may be as a result of the high standards of environmental sanitation and hygiene obtainable in those areas. The apparently low prevalence of helminthes in the present study may be due to abuse of cheap and easily available over the counter antihelminthic medications used by the general population.

The prevalence rate of parasitic infestation in South America varies from $27 \%$ to $69 \%{ }^{(25)}$ reflecting striking geographical variation in the subcontinent. For instance, in Brazil, in one study, Strongyloides stercoralis (12\%) was the most frequently isolated parasite, followed by the Coccidians (Isospora 7\%, and Cryptosporidium 4\%). In a similar work ${ }^{(26)}$ the Protozoon's were the predominant parasites with Giardia lamblia (16\%) being the commonest followed by Cryptosporidium parvum (7\%) and Endolimax nana (3.5\%). These findings differ from those of the current study, where the Protozoons were predominant (54.7\%) with Coccidian forming the bulk of the Protozoon parasites isolated (32.6\%), even though Entamoeba histolytica (22.1\%) was the single most common parasite. This observation may probably be a reflection of the geographical and ecological variation in the distribution of parasites, rather than differences in study methodology since study population was the same.

In southern ${ }^{(27)}$ and northern India ${ }^{(28)}$ there were high detection rates of opportunistic parasites compared to nonopportunistic parasites with prevalence rates ranging from $18.6 \%$ to $31 \%$ and $11 \%$ to $11.8 \%$ for Isospora belli and Cryptosporidium parvum respectively. Studies in Nepal ${ }^{(29)}$ and South Korea ${ }^{(30)}$ have also shown similar results with variable prevalence of Coccidian and non-opportunistic Protozoan parasites. This is at variance with the findings in this study in which a non-opportunistic parasite, Entamoeba histolytica was the most common parasite followed by the Coccidian highlighting the high endemicity and emerging importance of opportunistic Protozoan parasites in HIV infected patients in the Asian subcontinent as compared to sub Saharan Africa.

\section{Conclusion}

The high (54.7\%) prevalence of parasitosis among ART naïve HIV infected patients at AKTH and IDH should be of concern in view of its serious health burden on this category of patients (i.e. PLWA) while majority of the parasites remain undetected. Adoption of routine diagnosis with specific and more sensitive technique for the defection of parasitosis in ART naïve infected patients is imperative to guide all inclusive chemotherapy so as to limit parasite transmission and severe morbidity and high mortality among this category of patients. 


\section{International Journal of Science and Research (IJSR) \\ ISSN (Online): 2319-7064}

Index Copernicus Value (2013): 6.14 | Impact Factor (2014): 5.611

Table 1: General Demographic Characteristics of the Study Population

\begin{tabular}{|c|c|}
\hline Characteristics & Frequency $N=95(100 \%)$ \\
\hline Gender & No (\%) \\
\hline Male & $45(47.4)$ \\
\hline Female & $50(52.6)$ \\
\hline \multicolumn{2}{|l|}{ Marital Status } \\
\hline Married & $52(54.7)$ \\
\hline Divorced & 17 (17.9) \\
\hline Single & $13(13.70)$ \\
\hline Others & $13(13.7)$ \\
\hline \multicolumn{2}{|l|}{ Occupation } \\
\hline Unemployed & $40(42.1)$ \\
\hline Farming & $12(12.6)$ \\
\hline Trading & $12(11.6)$ \\
\hline Civil Service & $8(8.4)$ \\
\hline Driving & $4(4.2)$ \\
\hline Others & $19(21)$ \\
\hline \multicolumn{2}{|l|}{ Educational Level } \\
\hline None & $11(11.6)$ \\
\hline Arabic Alone & $41(43.2)$ \\
\hline Arabic + Primary & $6(6.3)$ \\
\hline Primary & $20(21.1)$ \\
\hline Secondary & $13(13.7)$ \\
\hline Post Secondary & $4(4.2)$ \\
\hline \multicolumn{2}{|l|}{ Place of Residence } \\
\hline Slum & $33(34.7)$ \\
\hline Urban & 32 (33.7) \\
\hline \multirow{2}{*}{$\begin{array}{l}\text { Urban } \\
\text { Rural }\end{array}$} & $30(31.6)$ \\
\hline & Mean \pm SD \\
\hline Age (Years) & $36.01 \pm 10.30$ \\
\hline \multirow{2}{*}{ Weight (Kg) } & $48.30 \pm 10.40$ \\
\hline & Median (Range) \\
\hline CD4 Count (Cell/ $/ \mathrm{l})$ & $84(4-658)$ \\
\hline
\end{tabular}

Key: SD, Standard Deviation; CD, Cluster of Differentiation

Table 2: Comparison of Demographic and Environmental Characteristics of Patients with and without Parasitic Infestation

\begin{tabular}{|c|c|c|c|c|}
\hline Characteristic & Parasitic infestation & Without Parasitic Infestation & Statistical Test & P value \\
\hline & Median (range) & Median (Range) & & \\
\hline \multirow[t]{2}{*}{ Duration of diarrhea (weeks) } & $5.0(4-84)$ & $6.0(4-52)$ & Mann-Whitney & 0.05 \\
\hline & Mean \pm SD & Mean \pm SD & & \\
\hline Age (years) & $34.0 \pm 8.98$ & $37.81 \pm 11.52$ & T test & 0.09 \\
\hline Stool frequency (bowel motions per day) & $4.87 \pm 2.30$ & $4.80 \pm 2.20$ & T test & 0.87 \\
\hline & $\begin{array}{l}\text { No (\%) } \\
(n=52)\end{array}$ & $\begin{array}{l}\text { No (\%) } \\
(n=43)\end{array}$ & & \\
\hline $\begin{array}{l}\text { Gender } \\
\text { Male } \\
\text { Female }\end{array}$ & $\begin{array}{l}27 \text { (51.9) } \\
25 \text { (48.10 }\end{array}$ & $\begin{array}{l}18(41.9) \\
25(58.1)\end{array}$ & Chi square & 0.33 \\
\hline Tap water consumption & 19(36.5) & 15(34.9) & T test & 0.87 \\
\hline Raw vegetable consumption & $20(38.5)$ & $13(34.9)$ & T test & 0.40 \\
\hline VIP toilet/water closet & $6(11.5)$ & $4(9.3)$ & T test & 0.72 \\
\hline Pit latrine & $43(82.7)$ & $37(86.0)$ & T test & 0.66 \\
\hline $\begin{array}{c}\text { Residence } \\
\text { Urban } \\
\text { Slum } \\
\text { Rural } \\
\end{array}$ & $\begin{array}{l}18(34.6) \\
18(34.6) \\
16(30.8)\end{array}$ & $\begin{array}{l}14(32.6) \\
15(34.9) \\
14(32.6)\end{array}$ & $\begin{array}{c}\text { Chi square } \\
\text { (Using 3x2 contingency table) }\end{array}$ & \\
\hline
\end{tabular}

Key: VIP, Ventilation Improved 


\section{International Journal of Science and Research (IJSR) \\ ISSN (Online): 2319-7064 \\ Index Copernicus Value (2013): 6.14 | Impact Factor (2014): 5.611}

Table 3: Comparison of AIDS-Defining Characteristics of Patients with and without Parasitic Infestation

\begin{tabular}{|c|c|c|c|c|}
\hline Characteristic & Parasitic infestation & Without Parasitic Infestation & Statistical Test & $P$ value \\
\hline & $\begin{array}{l}\text { No (\%) } \\
(n=52)\end{array}$ & $\begin{array}{l}\text { No (\%) } \\
(n=43)\end{array}$ & & \\
\hline $\begin{array}{l}\text { CD4 cell count } \\
\text { (cells/ } / \mu \mathrm{l} \\
\leq 200 \\
>200\end{array}$ & $\begin{array}{l}41(78.8) \\
11(21.2)\end{array}$ & $\begin{array}{c}37(86.0) \\
6(14.0)\end{array}$ & Chi square & 0.36 \\
\hline $\begin{array}{l}\text { WHO Staging } \\
\text { of HIV infection } \\
3 \\
4\end{array}$ & $\begin{array}{c}51(98.1) \\
1(1.9)\end{array}$ & $\begin{array}{c}42(97.7) \\
1(2.3)\end{array}$ & Fisher's exact & 0.80 \\
\hline $\begin{array}{c}\text { CDC Staging } \\
\text { of HIV infection } \\
\text { AIDS } \\
\text { Non AIDS }\end{array}$ & $\begin{array}{c}48(92.3) \\
4(7.7)\end{array}$ & $\begin{array}{c}36(83.7) \\
7(16.3)\end{array}$ & Fisher's exact & 0.33 \\
\hline
\end{tabular}

CDC-Centre for Disease Control

WHO-World Health Organization

Table 4: Distribution of Parasites Isolated from Patients

\begin{tabular}{|c|c|}
\hline Parasites Isolated & $\begin{array}{c}\text { Frequency (\%) } \\
\text { N=95 }\end{array}$ \\
\hline Entamoeba histolytica & $21(22.1)$ \\
\hline Hookworm (Necator Americanus) & $6(6.3)$ \\
\hline Hymenolepsis nana & $3(3.2)$ \\
\hline Ascaris lumbricoides & $2(2.1)$ \\
\hline Schistosoma mansonii & $2(2.1)$ \\
\hline Fasciola hepatica & $1(1.1)$ \\
\hline Opportunistic Parasites & \\
\hline Microsporidium & $16(16.8)$ \\
\hline Cryptosporidium & $12(12.6)$ \\
\hline Isospora & $2(2.1)$ \\
\hline Cyclospora & $1(1.1)$ \\
\hline
\end{tabular}

Table 5: Comparison of Patients with Different Patterns of Parasitic Infestations

\begin{tabular}{|c|c|c|c|c|c|c|}
\hline Characteristic & No Parasite & $\begin{array}{c}\text { Non- } \\
\text { Opportunistic } \\
\text { Only }\end{array}$ & Opportunistic Only & Mixed & ANOVA & \\
\hline & Mean \pm SD & Mean \pm SD & Mean \pm SD & Mean \pm SD & $\mathrm{F}$ & $\mathrm{P}$ value \\
\hline Age (Years) & $37.8 \pm 11.5$ & $33.8 \pm 9.1$ & $34.1 \pm 8.0$ & $38.0 \pm 11.1$ & 1.176 & 0.30 \\
\hline Weight (Kg) & $48.1 \pm 9.7$ & $48.4 \pm 10.3$ & $47.8 \pm 11.9$ & $49.7 \pm 12.1$ & 0.069 & 0.90 \\
\hline BMI $\left(\mathrm{Kg} / \mathrm{m}^{2}\right)$ & $17.3 \pm 3.6$ & $17.5 \pm 3.4$ & $18.1 \pm 4.4$ & $19.1 \pm 4.3$ & 0.582 & 0.63 \\
\hline $\begin{array}{l}\text { Stool frequency } \\
\text { (motions/day) }\end{array}$ & $4.8 \pm 2.2$ & $5.0 \pm 2.8$ & $4.5 \pm 1.6$ & $5.3 \pm 2.3$ & 1.083 & 0.36 \\
\hline & Mean (range) & Mean(Range) & Mean(Range) & Mean(Range) & & \\
\hline $\begin{array}{l}\text { Duration of Diarrhea } \\
\text { (weeks) }\end{array}$ & $8.6(4.0-52)$ & $13.0(4.0-84)$ & $11.5(4.0-52)$ & $17.0(4.0-52)$ & 0.316 & 0.81 \\
\hline & $\begin{array}{l}\text { No (\%) } \\
(n=43)\end{array}$ & $\begin{array}{c}\text { No (\%) } \\
n=24)\end{array}$ & $\begin{array}{l}\text { No }(\%) \\
(\mathrm{n}=20)\end{array}$ & $\begin{array}{c}\text { No }(\%) \\
(n=8)\end{array}$ & Chi Square & $P$ value \\
\hline $\begin{array}{l}\text { CD4 cell count } \\
\text { (cells/ul) } \\
<200 \\
>200\end{array}$ & $\begin{array}{l}37(86.0) \\
6(14.0)\end{array}$ & $\begin{array}{c}19(79.2) \\
5(20.8)\end{array}$ & $\begin{array}{l}14(30.00) \\
6(70.00)\end{array}$ & $\begin{array}{c}8(100.0) \\
0(0.0)\end{array}$ & 4.33 & 0.23 \\
\hline $\begin{array}{l}\text { Gender } \\
\text { Male } \\
\text { Female }\end{array}$ & $\begin{array}{l}18(41.9) \\
25(58.1)\end{array}$ & $\begin{array}{c}16(66.7) \\
8(33.3)\end{array}$ & $\begin{array}{c}6(30.0) \\
14(70.0)\end{array}$ & $\begin{array}{l}5(62.5) \\
3(37.5)\end{array}$ & 7.26 & 0.06 \\
\hline $\begin{array}{l}\text { WHO Staging of HIV } \\
\text { infection } \\
3 \\
4\end{array}$ & $\begin{array}{l}42(97.7) \\
1 * 2.3)\end{array}$ & $\begin{array}{c}24(100.0) \\
0(0.0)\end{array}$ & $\begin{array}{c}19(95.0) \\
1(5.0)\end{array}$ & $\begin{array}{c}8(100.0) \\
0(0.0)\end{array}$ & 1.51 & 0.68 \\
\hline CDC Staging of HIV & & & & & & \\
\hline
\end{tabular}




\section{International Journal of Science and Research (IJSR) \\ ISSN (Online): 2319-7064}

Index Copernicus Value (2013): 6.14 | Impact Factor (2014): 5.611

\begin{tabular}{|c|c|c|c|c|c|c|}
\hline infection AIDS & $36(83.7)$ & $20(83.3)$ & $20(100.0)$ & $8(100.0)$ & 5.20 & 0.16 \\
Non AIDS & $7(16.3)$ & $4(16.7)$ & $0(0.0)$ & $0(0.0)$ & \\
\hline
\end{tabular}

Key: BMI - Body Mass Index

WHO - World Health Organization

CDC - Centre for Disease Control

* Mixed is a combination of opportunistic and non-opportunistic parasitic infestations

Table 6: Comparison of Demographic and Environmental Characteristics of Patients with Single and Multiple Parasitic Infestations

\begin{tabular}{|c|c|c|c|c|}
\hline Characteristic & Single & *Multiple & Statistical Test & $P$ Value \\
\hline & Mean SD & Mean SD & & \\
\hline Age (Years) & $34.20 \pm 8.80$ & $35.5 \pm 9.7$ & T-test & 0.60 \\
\hline Weight & $49.05 \pm 10.98$ & $46.31 \pm 11.36$ & T-test & 0.82 \\
\hline BMI $\left(\mathrm{Kg} / \mathrm{m}^{2}\right)$ & $18.12 \pm 3.86$ & $17.54 \pm 4.16$ & T-test & 0.69 \\
\hline & $\begin{array}{l}\text { No (\%) } \\
(\mathrm{n}=39)\end{array}$ & $\begin{array}{l}\text { No (\%) } \\
(\mathrm{n}=13)\end{array}$ & & \\
\hline $\begin{array}{l}\text { Gender } \\
\text { Male } \\
\text { Female }\end{array}$ & $\begin{array}{l}19(51.4) \\
20(48.6)\end{array}$ & $\begin{array}{l}8(61.5) \\
5(36.5)\end{array}$ & Chi-square & 0.42 \\
\hline $\begin{array}{l}\text { Residence } \\
\text { Urban } \\
\text { Slum } \\
\text { Rural }\end{array}$ & $\begin{array}{l}16(35.1) \\
14(40.6) \\
9(24.30\end{array}$ & $\begin{array}{l}4(30.8) \\
2(15.4) \\
7(53.8)\end{array}$ & $\begin{array}{c}\text { Chi square (using } 3 \times 2 \\
\text { contingency table) }\end{array}$ & $\begin{array}{c}0.11 \text { (not valid, } \\
\text { Cochran's criteria not } \\
\text { met) }\end{array}$ \\
\hline Tape Water & $16(43.2)$ & $3(23.1)$ & T-test & 0.50 \\
\hline Raw vegetables and fruits & $15(40.5)$ & $5(38.5)$ & T-test & 0.70 \\
\hline
\end{tabular}

VIP - Ventilation Improved

BMI - Body Mass Index

CD - Cluster for Differentiation

HIV - Human Immunodeficiency Virus

WHO - World Health Organization

CDC - Centre for Disease Control

AIDS - Acquired Immunodeficiency Syndrome

*Multiple refers to more than one parasitic infestation

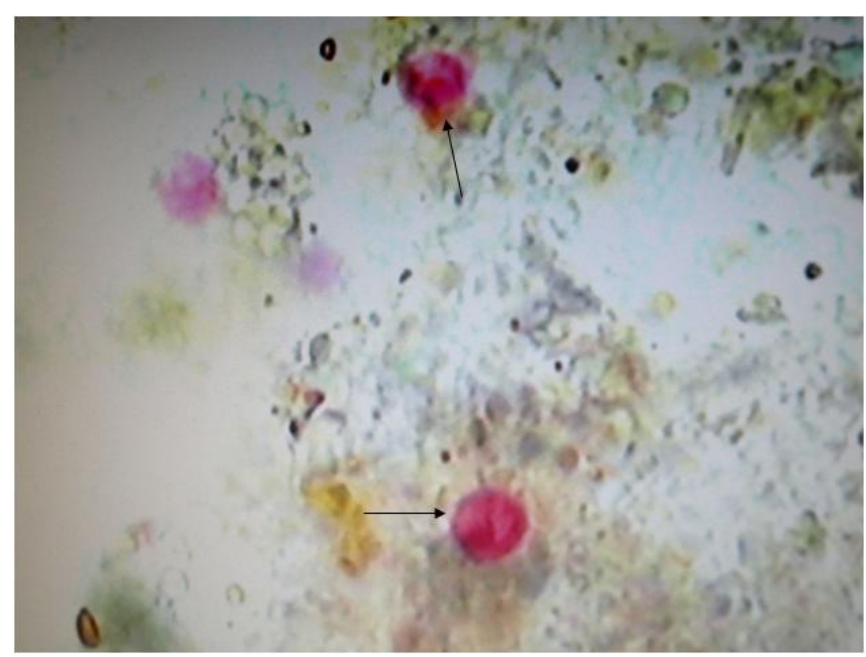

Figure 1: Photomicrograph showing oocysts of Cryptosporidium (arrowed) isolated from stool (Modified ZN Stain with X1000 oil immersion objective lens)

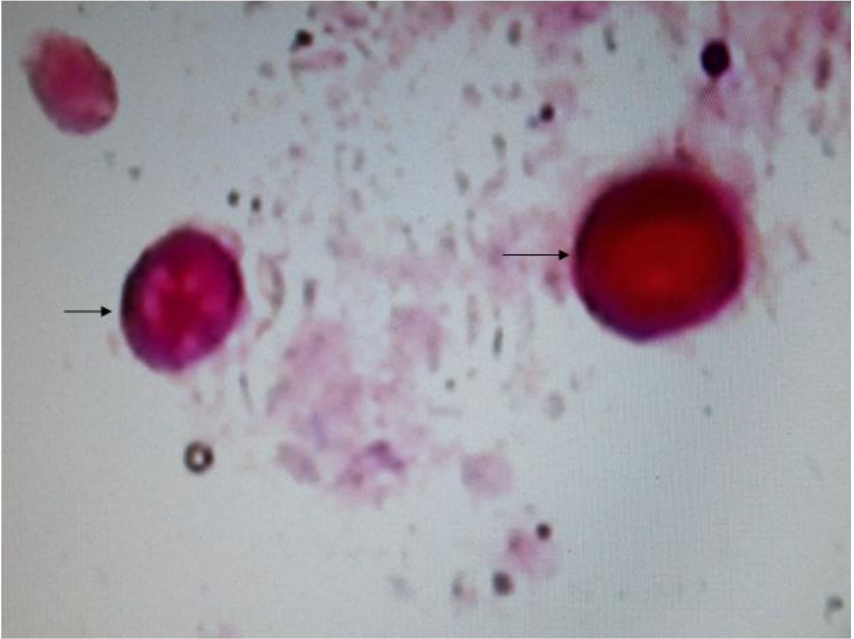

Figure 2: Photomicrograph of two Cyclospora oocysts (arrowed) obtained from a patients stool, using modified ZN Stain (X1000 magnification) 


\section{International Journal of Science and Research (IJSR) \\ ISSN (Online): 2319-7064 \\ Index Copernicus Value (2013): 6.14 | Impact Factor (2014): 5.611}

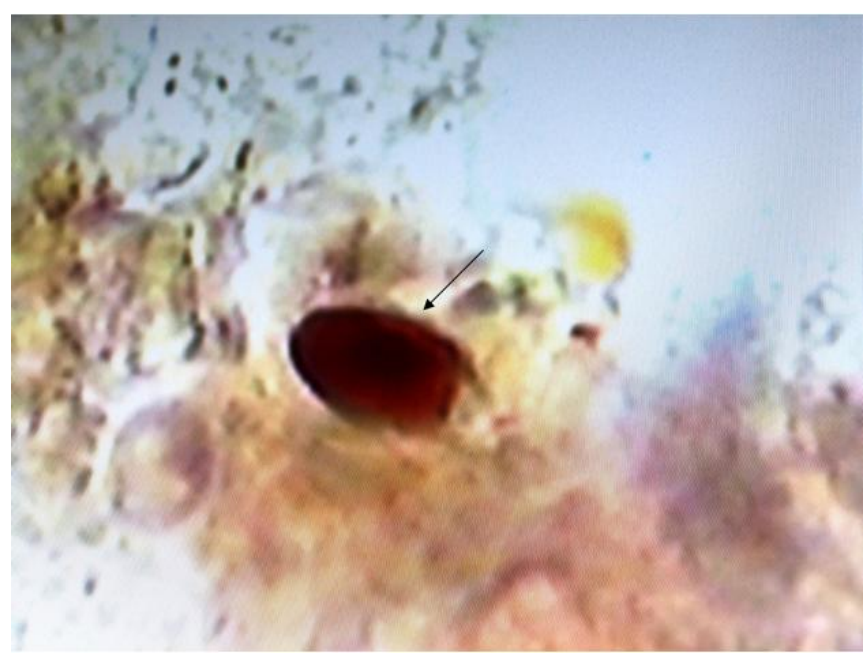

Figure 3: Photomicrograph of Isospora oocyst (arrowed) in a patient's stool with Modified ZN Stain at X1000 magnification using oil immersion lenses

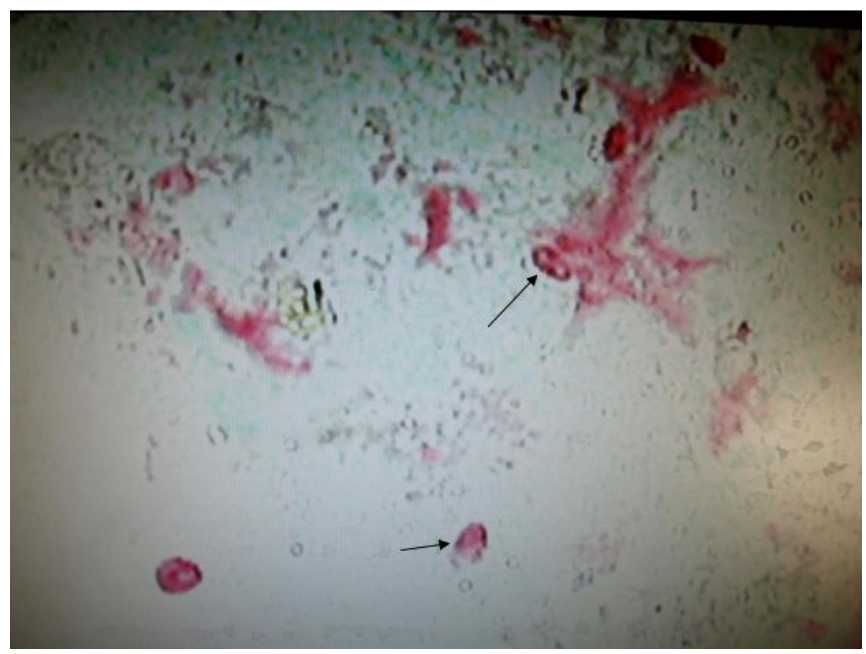

Figure 4: Photomicrograph of Microsporidial oocyst (arrowed) in stool Stained with Modified Trichrome Stain (X1000 oil immersion lens)

\section{References}

[1] Smith, P.D., Quinn, T.C., Strober, W. et al., NIH: Conference: Gastrointestinal Infections in AIDS. Ann. Intern. Med.1992; 116: 63-77

[2] Lew, E.A., Poles, M.A., Dietrich, D.T. Diarrheal Diseases Associated with HIV Infection. Gastroenterol. Clin. North Am. 1997; 26(2): 259-290.

[3] Kaslow, R.A., Phair, J.P., Frieman, H.B. et al., Human Immunodeficiency Virus: Clinical Manifestations and their Relationship to Immune Deficiency. Ann. Intern.Med.1987; 107: 474-480.

[4] May, G.R., Gill, M. J., Church, D.L. Sutherland, L.R., Infected Patients. Diag Dis. Sci. 1996; 41: 1794-1799.

[5] Dwivedi, K. K., Prasad, G., Saimi, S. et al., Enteric Opportunistic Parasites among HIV infected individuals: Associated Risk Factors and Immuno Status. Japan J. Infect. Dis. 2007; 60: 76-81.

[6] Buyukbaba, B.O., Uysal, H., Alan, S., Nazlican, AIDS Patients. Microbiyol. Bul. 2004; 38 (1-2): 121-128.

[7] gulick, R., Mellor, J., Havlir, D. et al., Lamivudine in Adults with Human Immunodeficiency Virus
Infection and Prior Antiretroviral Therapy. N. Engl. J. Clin. Gastroenterol. 2007: 41(5): 484-490.

[8] UNIADS. New Report Card on Global HIV/AIDS epidemic. UNAIDS New Estimates of People Living with HIV in Different Regions of the World. http://news.sciencemag.org/funding/2005/07/newreport-card-global-hivaids-epidemic. Accessed 14 July, 2015.

[9] AVERT. HIV and AIDS in Nigeria: www.avert.org/hiv-aids-Nigeria. Accessed 22 July, 2015.

[10] Adedoyin, M.A, Awogun, I.A., Juergensen, T., Prevalence of Intestinal Parasitosis in Relationship to Diarrhea among Children in Ilorin. West Afr. J. Med. 1990; 9(2): 83-88.

[11] Anosike, J.C., Nwoke, B.E., Onwuliri, C.O. et al., Prevalence of Parasitic Disease among Nomadic Fulanis of South-Eastern Nigeria. Ann. Agric. Environ. Med. 2004; 11(2): 211 - 225.

[12] UNAIDS. The Report of Global AIDS Epidemic, 2007: AIDS Epidemic Update. Joint United Nations Programme on HIV/AIDS (UNAIDS) and the World Health Organization WHO 2008.

[13] UNAIDS. Sub-Saharan Africa AIDS Epidemiological Summary. Joint United Nations Programme on HIV/AIDS UNAIDS (WHO), 2008.

[14]Katabira, E.T. Epidemiology and Management of Diarrheal Diseases in HIV-Infected Patients. Intern. J. Infect. Dis. 1999; 3(3): 164-167.

[15] Nwokediuko, S., Bojuwoye, B., Ozumba, U.C., OZoh, G. Peculiarities of Chronic Diarrhea in Enugu, Southern Nigeria. J. Health Sci. 2002; 48 (5): 435440.

[16] Keshinro, I.B., Musa, B.O. P. Cellular Immunity and Diarrhea Disease Amongst Patients with Human Immunodeficiency Virus 1 and 2 in Zaria. Nig. J. Med. 2003; 12(1): 22-26.

[17] Ikeh, E.I., Obadofin, M.O. Brindero B. et al. Intestinal Parasitism in Magama Gumau Rural Village and Jos Township in North-Central Nigeria. Nig. Postgrad. Med. J. 2007; 14(4): 290-295.

[18] Adesiyi, Y. O., Lawal, R.O., Taiwo, S.S. et al. Cryptosporidiosis in HIV-Infected Patient with Diarrhea in Osun State, Southwestern Nigeria. Europ. J. Med. 2007; 4(3): 119-122.

[19] Gumbo, T., Sarba, S., Gangaidzo, I.T. et al. Intestinal Parasites in Patients with Diarrhea and Human Immunodeficiency Virus Infection in zimbawe. AIDS 1999; 13()70: 819-821.

[20] Sarfati, C., Bourgeois, A., Menoti, J. et al. Prevalence of Intestinal Parasites including Microsporidia in Human Immunodeficiency Virus-infected Adults in Cameroon. Ann. J. Trop. Med. Hyg. 2006; 74(1): 162164.

[21] Conlon, C.P., Pinching, A.J., Perera, C.U. et al. HIV Related Enteropathy in Zambia: A Clinical Microbiological and Histological Study. Ann. J. Trop. Med. Hyg. 1990; 42(1): 83-88.

[22] Endeshaw, T., Mohammed, H., Woldemicheal, T. Cryptosporidium parvum and other Intestinal Parasites among Diarrhea Patients Referred to Ethiopian Health and Nutrition Research Institution 
(EHNRI) in Ethiopai. Ethiop. Med. J. 2004; 42(3): 195-198.

[23] Bonacini, M., Skodras, G., Quison, S., Kragel, P. Prevalence of Enteric Pathogens in HIV Related Diarrhea in the Mid-West. AIDS Pat. Care STDS. 1999; 13(3): 179-184.

[24] Cotte, L., Rabodonirina, M., Piens, M.A. et al. The Prevalence of Intestinal Protozoans in French Patients with HIV. Acquir. Immune Defic Syndr. 1993; 6(9): 1024-1029.

[25] Cimerman, S., Cimerman, B., Law, D.S. Prevalence of Intestinal Parasitic Infections in Patients with Acquired Immunodeficiency Syndrome in Brazil. Int. J. Infect. Dis. 1999; 3(4): 202-206.

[26] Silva, C. V., Ferreira, M.S., Borges, A.S., Costacruz, J. M. Intestinal Infection in HIV/AIDS Patients: Experience at a Teaching Hospital in Central Brazil. Scand. J. Infect. Dis. 2005; 37(3): 211-215.

[27] Kumar, S.S., Ananthan, S., Lakshmi, P. Intestinal Parasitic Infection in HIV Infected Patients with Diarrhea in Chennai. Indian J. Med. Microbiol. 2002; 20(2): 88-91.

[28] Prasad, K.N., Nag. V. L., Dhole, T. N., Ayyagari, A. Identification of Enteric Pathogens in HIV Positive Patients with Diarrhea in Northern India. India $J$. Health Popul. Nutr. 2000; 18(1): 22-26.

[29] Sapkota, D., Ghimire, P., Manadhar, S. Enteric Parasitosis in Patient $s$ with Human Immunodeficiency Syndrome (AIDS) in Nepal. J. Nepal Health Res. Council. 2004; 21(1) 124-129.

[30] Guk, S.M., Seo, M., Park, Y.K. et al. Parasitic Infection in HIV Infected Patients Who visited Seoul National University Hospital during the period 19952003. Korean J. Parasitol. 2005; 43(1): 1-5 